\title{
Cholangiocarcinoma and brain lesions: an extremely rare finding
}

\author{
Aibek E Mirrakhimov, Nwabundo Nwankwo, Teresita Zdunek, Nora Bucher
}

Department of Internal Medicine, Saint Joseph Hospital, Chicago, Illinois, USA

\section{Correspondence to} Dr Aibek E Mirrakhimov, amirrakhimov1@gmail.com
To cite: Mirrakhimov $A E$ Nwankwo N, Zdunek T, et al. BMJ Case Rep Published online: [please include Day Month Year] doi:10.1136/bcr-2013009235

\section{DESCRIPTION}

A 55-year-old man with a medical history of intrahepatic cholangiocarcinoma treated with gemcitabine and cisplatin with tumour chemoembolisation. However, the patient failed the initial therapy and was subsequently switched to fluorouracil and oxaliplatin with folinic acid. CT of the chest and abdomen showed new lesions consistent with metastatic disease in the liver and lungs and worsening ascites.

In February 2013, the patient was admitted to the hospital because of progressive left upper extremity weakness and a mechanical fall. The brain MRI showed right subcortical frontal lobe enhancing lesion concerning for metastatic disease (figure 1). Neurosurgical service was consulted for possible biopsy. Neurosurgery deferred the need for biopsy and the patient was started on wholebrain radiation therapy with resolution of his neural symptoms. Unfortunately, the patient died 1 month after brain irradiation.

Cholangiocarcinoma is a rare tumour arising from either extrahepatic or intrahepatic bile ducts with an approximate occurrence of 30640 new cases annually in the USA. ${ }^{1}$ Common risk factors include pre-existent liver and biliary disease, parasitic diseases involving biliary tree, diabetes, obesity, HIV infection and toxic exposures. ${ }^{2}$ Surgical resection is the mainstay of treatment for cholangiocarcinoma. ${ }^{3}$ However, many times the disease is present at an advanced stage making surgery not amenable.

The presence of brain metastasis owing to cholangiocarcinoma is an extremely rare event, with only a few published reports. In a most recent report from Thailand, the incidence rate of brain metastases was only $0.15 \%$ and was associated with a decreased survival. ${ }^{4}$ Cholangiocarcinoma is known to be a poorly vascularised tumour, which may explain why patients with cholangiocarcinoma rarely develop brain metastases.

In conclusion, despite being an extremely rare finding, brain metastases from cholangiocarcinoma may occur. The presences of brain metastases portray an extremely poor prognosis. ${ }^{2}$ Therefore, clinicians should keep their minds open and consider brain metastases in patients with cholangiocarcinoma and with a new onset of neurological symptoms.

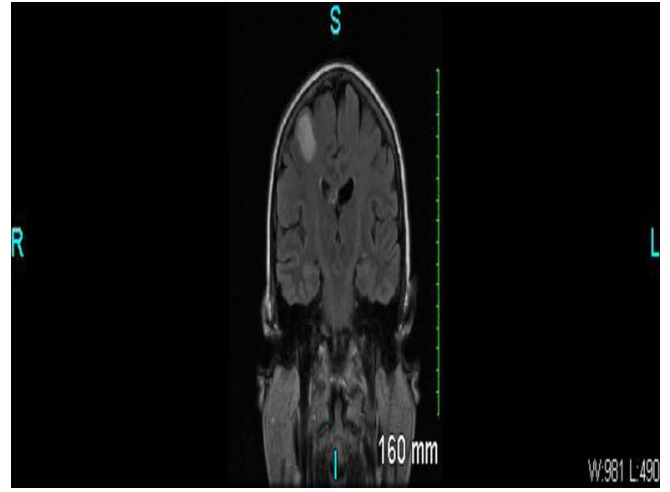

Figure 1 White matter right frontal lobe enhancing lesion concerning for metastatic disease.

\section{Learning points}

- Cholangiocarcinoma is a rare tumour arising from intrahepatic or extrahepatic bile ducts.

- Brain metastases from cholangiocarcinoma are extremely rare.

- Poor tumour vascularisation may explain why the tumour rarely metastasise to the central nervous system.

- Clinicians should keep their minds open and consider brain metastases in patients with cholangiocarcinoma with a new onset of neurological symptoms.

\section{Competing interests None.}

Patient consent Obtained.

Provenance and peer review Not commissioned; externally pee reviewed.

\section{REFERENCES}

1 Siegel R, Naishadham D, Jemal A. Cancer statistics, 2013. CA Cancer J Clin 2013;63:11-30.

2 Tyson GL, El-Serag HB. Risk factors for cholangiocarcinoma. Hepatology 2011:54:173-84.

3 Friman S. Cholangiocarcinoma-current treatment options. Scand J Surg 2011;100:30-4.

4 Chindaprasirt J, Sookprasert A, Sawanyawisuth K, et al. Brain metastases from cholangiocarcinoma: a first case series in Thailand. Asian Pac J Cancer Prev 2012;13:1995-7. 


\section{Images in...}

Copyright 2013 BMJ Publishing Group. All rights reserved. For permission to reuse any of this content visit http://group.bmj.com/group/rights-licensing/permissions.

BMJ Case Report Fellows may re-use this article for personal use and teaching without any further permission.

Become a Fellow of BMJ Case Reports today and you can:

- Submit as many cases as you like

- Enjoy fast sympathetic peer review and rapid publication of accepted articles

- Access all the published articles

- Re-use any of the published material for personal use and teaching without further permission

For information on Institutional Fellowships contact consortiasales@bmjgroup.com

Visit casereports.bmj.com for more articles like this and to become a Fellow 